\title{
Perlindungan Kekayaan Intelektual terhadap Produk Teri Biru Seira dan Kerupuk Ikan Tanimbar sebagai Industri Kreatif Masyarakat di Kota Saumlaki
}

\author{
Nia Kurniati,* Rika Ratna Permata,** Reginawanti Hindersah,*** Sondi \\ Kuswaryan, ${ }^{* * * *}$ dan Yongky Souisa***** \\ DOI: https://doi.org/10.22304/pjih.v4n3.a5
}

\begin{abstract}
Abstrak
Pemanfaatan sumber daya alam di laut oleh masyarakat Tanimbar berupa ikan teri biru di wilayah perairan laut Yamdena, Maluku Tenggara Barat mengandung potensi yang bernilai bagi pengembangan ekonomi masyarakat lokal setempat. Pengolahan ikan dalam bentuk penganan kerupuk Tanimbar merupakan salah satu bentuk industri kreatif masyarakat setempat karena merupakan pemanfaatan yang berasal dari kreatifitas keterampilan individu untuk menciptakan kesejahteraan dan lapangan kerja dengan menghasilkan dan mengeksploitasi daya kreasi dan daya cipta individu, sehingga pemerintah perlu memberikan perlindungan kekayaan intelektual untuk memberikan kepastian hukum bagi pemilik pengembangan usaha tersebut. Artikel ini menemukan bahwa: pertama, perlindungan kekayaan intelektual berupa hak merek sebagai tanda pembeda memberi jaminan bahwa produknya adalah berbeda dengan produk barang lainya, dan juga sebagai roh perdagangan yang mendukung perkembangan bisnis ekonomi kreatif masyarakat lokal Tanimbar; kedua, pendaftaran hak merek kolektif atas produk olahan ikan teri biru berupa penganan kerupuk Tanimbar memberi kepastian hukum dan perlindungan hukum atas industri kreatif masyarakat Tanimbar dan memberdayakan usaha mikro, kecil, dan menengah dalam pengembangan industri kreatif yang berkelanjutan; dan ketiga dapat dilindungi berdasarkan indikasi geografis.
\end{abstract}

Kata kunci: hukum merek, indikasi geografis, industri kreatif, merek kolektif, perlindungan hukum.

\section{Intellectual Property Protection of Seira Blue Anchovy and Tanimbar Fish Crackers Products as the Creative Industry of Saumlaki City Community}

\footnotetext{
Abstract

Utilization of marine natural resources by the community of Tanimbar in the form of blue anchovies in the marine areas of Yamdena, Maluku Tenggara Barat holds a valuable potential towards the economic development of the local community. The processing of fish in the form of Tanimbar Crackers is one of the form of the local community's creative

PADJADJARAN Jurnal IImu Hukum Volume 4 Nomor 3 Tahun 2017 [ISSN 2460-1543] [e-ISSN 2442-9325]

* Dosen Fakultas Hukum Universitas Padjadjaran, Jl. Dipati Ukur 35, nia.kurniati@unpad.ac.id, S.H., M.H., Dr. (Universitas Padjadjaran).

** Dosen Fakultas Hukum Universitas Padjadjaran, Jl. Dipati Ukur 35, permata_rika@yahoo.com, S.H., M.H., Dr. (Universitas Padjadjaran).

*** Dosen Fakultas Pertanian Universitas Padjadjaran, Jl. Raya Bandung Sumedang Km. 21 Jatinangor, reginawanti@ unpad.ac.id, Ir., MP., Dr. (Universitas Padjadjaran).

**** Dosen Fakultas Peternakan Universitas Padjadjaran, Jl. Raya Bandung Sumedang Km. 21 Jatinangor, sondikus@ yahoo.com, Ir. (Institut Pertanian Bogor), MS. (Universitas Padjadjaran).

${ }^{* * * * *}$ Mahasiswa Sekolah Pascasarjana, Program Studi Inovasi Regional, Universitas Padjadjaran, JI. Dipati Ukur 35, ysouisa@gmail.com, S.STP (Sekolah Tinggi Pemerintahan Dalam Negeri).
} 
industry because it is a form of utilization that comes from the creativity of each individual skills to create welfare and employment by producing and exploiting the creative force of the individual, thus the government needs to provide intellectual property protection to provide legal certainty for the business development owner. The research method used is judicial normative research with judicial qualitative data analysis. The result of the research are as follows: first; protection of intellectual property in the form of brand right as a distinctive marker gives assurance that its products are different from other goods products, and also as a trading spirit that supports the business development of Saumlaki's local community creative economy; second, collective trademark rights registration of blue anchovy processed products in the form of Tanimbar crackers gives a legal certainty and protection for the creative industry of Tanimbar's community for the utilization of micro, small, and medium businesses in developing a sustainable creative industry; and third, it can be protected by geographical indication.

Keywords: trademark law, geographical indication, creative industry, collective trademark, legal protection.

\section{A. Pendahuluan}

Sumber daya alam di laut kepulauan Tanimbar, Maluku Barat Daya, berupa ikan berpotensi sangat baik untuk pengembangan ekonomi masyarakat. Masyarakat kota Saumlaki, ibu kota kabupaten Maluku Barat Daya terbiasa mengkonsumsi ikan besar seperti tuna (cakalang), tenggiri, dan ikan dasar lainnya. Pada musim barat, ikan tenggiri melimpah dan berharga relatif murah. Di beberapa lokasi seperti Pulau Seira di wilayah barat Kepulaua Tanimbar, ikan berukuran kecil berlimpah antara lain ikan teri biru. Budaya lokal yang tidak terbiasa mengonsumsi ikan kecil menyebabkan ikan teri biru tidak dimanfaatkan padahal Ikan teri bermanfaat sangat baik bagi kesehatan karena mempunyai rasa gurih, dan mengandung kalsium, protein, lemak, karbohidrat, mineral, zat besi, fosfor. Sebagian dari jenis ikan yang ditangkap masyarakat beberapa kurang bernilai di pasar, namun tidak berarti tanpa makna, karena bagaimanapun ikan adalah sumber pangan dengan kandungan protein hewani yang sangat tinggi. Dengan pertimbangan baby fish yang sangat bernilai sebagai penganan jenis kripik serta bekal informasi dari masyarakat akan keberadaan jenis ikan yang murah dan kurang terperhatikan, maka diputuskan untuk membuat jenis penganan berupa baby fish goreng bumbu kering. Jenis ikan yang digunakan adalah ikan teri yang berasal dari perairan di Pulau Seira. ${ }^{1}$ Pembuatan gorengan teri disepakati dari teri biru yang banyak di Seira; teri ini berwarna hitam kebiruan dengan harga mentah Rp. 10.000 per kantung sekitar 1 kg. ${ }^{2}$

\footnotetext{
Badan Pemberdayaan Masyarakat Desa Kabupaten Maluku Tenggara Barat Kerja Sama dengan Direktorat Riset dan Pengabdian kepada Masyarakat Universitas Padjadjaran, "Program Implementasi Teknologi Tepat Guna Untuk Meningkatkan Pendapatan Keluarga di Kabupaten Maluku Tenggara Barat Provinsi Maluku", Laporan Akhir, 2016, hlm. 17.

2 Ibid., hlm. 29.
} 


\section{Gambar 1. Posisi strategis Kabupaten Maluku Tenggara Barat}

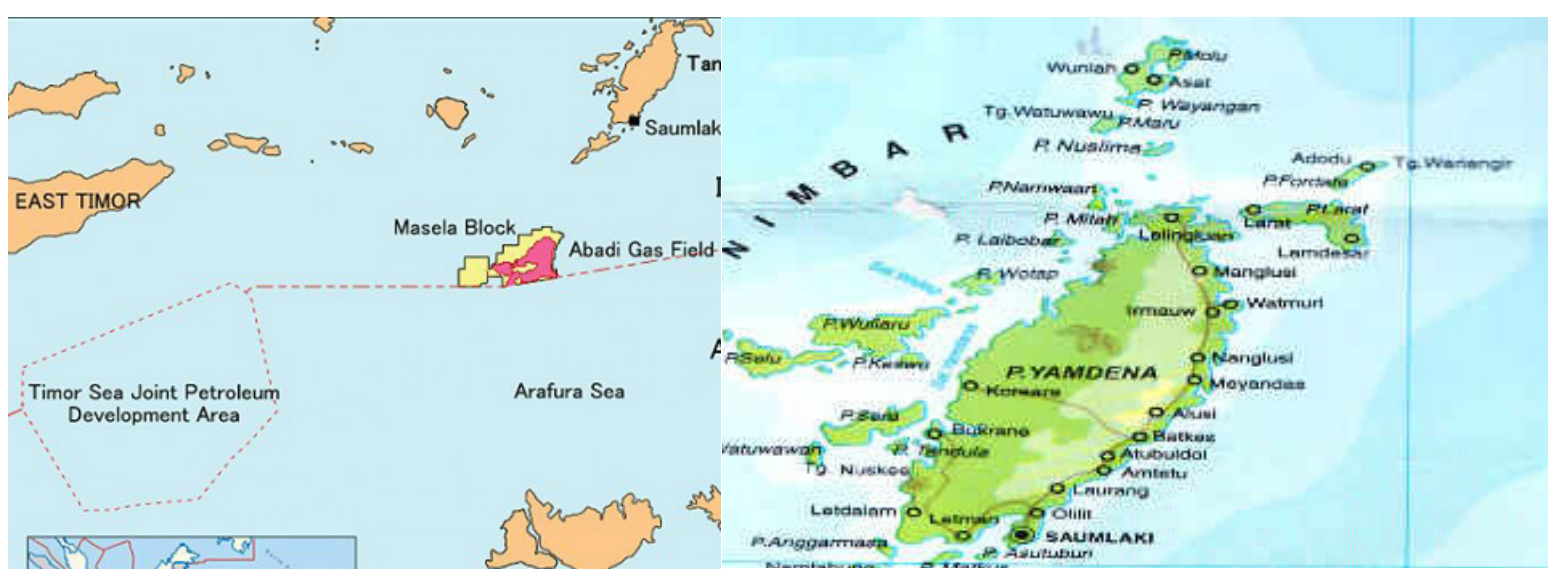

Melalui program Teknologi Tepat Guna Dinas Pemberdayan Masyarakat dan Desa serta Universitas Padjadjaran, kelompok ibu-ibu di kota Saumlaki didorong untuk mulai melakukan pengolahan hasil ikan. Penduduk Kepulauan Tanimbar yang termasuk ke dalam wilayah administrasi Kota Saumlaki belum terbiasa mengkonsumsi produk makanan berbasis ikan seperti kerupuk dan teri goreng tepung padahal tamu/wisatawan luar Saumlaki mengkonsumsi keduanya. Penganan kerupuk dapat dibuat dari ikan teri biru untuk menambah nilai ekonomis atas olahan ikan teri tersebut.

Pengembangan olahan ikan teri menjadi penganan kerupuk tersebut merupakan perkembangan industri ekonomi kreatif yang bisa dijadikan tonggak perekonomian khususnya yang terkait dengan aktifitas masyarakat dalam bidang ekonomi kreatif. Kelompok usaha bersama ibu-ibu rumah tangga di Kota Saumlaki telah memulai membuat teri goreng tepung dan kerupuk ikan. Mereka memberi merek dagang produk olahan tersebut sebagai Teri Biru Seira, di mana Seira adalah lokasi ikan teri itu hidup alami, dan Kerupuk Tanimbar. Kemasan kedua produk juga telah dibuat dengan desain yang menarik sesuai dengan tuntutan industri kreatif. Sehubungan dengan ini, Perserikatan Bangsa-Bangsa (PBB) Tahun 2013 menggambarkan pesatnya pertumbuhan ekonomi kreatif: ${ }^{3}$

"The creative economy has become a powerful transformative force in the world today. Its potential for development is vast and waiting to be unlocked. It is one of the most rapidly growing sectors of the world economy, not just in terms of income generation but also for job Creation and export earnings."

Industri ekonomi kreatif dapat dipahami sebagai suatu sistem kegiatan manusia yang berkaitan dengan kegiatan produksi, distribusi, pertukaran, dan konsumsi barang dan jasa yang bernilai kultural, artistik, estetika, intelektual dan

Ahmad Gusman Catursiswandi, Membangun Sinergi antara Warisan Budaya Tradisional, Keanekaragaman Hayati dan Ekonomi Kreatif: Perspektif Hak Kekayaan Intelektual, Dinamika Hukum dalam Pembangunan Berkelanjutan, Bandung: P.T. Alumni, 2017, hlm. 185. 
emosional bagi para pelanggan di pasar. Pada dasarnya industri kreatif berasal dari pemanfaatan kreativitas, keterampilan serta bakat individu untuk menciptakan kesejahteraan dan lapangan kerja dengan menghasilkan dan mengeksploitasi daya kreasi dan daya cipta individu. Industri ekonomi kreatif tidak lepas dari aspek-aspek hukum kekayaan intelektual yang merupakan hak eksklusif. Industri kreatif, ${ }^{4}$ sebagai suatu hak eksklusif Hak Kekayaan Intelektual (HKI) tidak dapat diganggu gugat, hal ini sejalan dengan prinsip droit inviolable et sacre dari hak milik itu sendiri, hak eksklusif itu tidak saja tertuju pada eigennaar tetapi juga berlaku bagi pembentuk undang-undang dan penguasa.

Perlindungan dalam perspektif kekayaan intelektual meliputi objek, jangka waktu, dan tindakan yang dapat dilakukan oleh pemegang kekayaan intelektual ada pihak lain yang tanpa hak menggunakan atau memanfaatkannya. Pemegang kekayaan intelektual dapat berkedudukan sebagai pencipta atau pendesain atau pihak yang mendapat kewenangan berdasarkan hukum untuk melakukan perbuatan sebagaimana tercantum dalam undang-undang yang bersangkutan. Objek perlindungan merupakan kreasi hasil pemikiran intelektual yang memenuhi persyaratan tertentu untuk mendapat perlindungan. Jangka waktu adalah kurun waktu tertentu yang diberikan oleh undang-undang untuk memanfaatkannya, sehingga pihak lain tidak dapat melakukan perbuatan tersebut tanpa izin pemegang hak. Sedangkan tindakan hukum adalah tindakan yang dapat dilakukan oleh pemegang kekayaan intelektual untuk melakukan upaya hukum, misalnya gugatan atau pembatalan hak karena pihak lain tersebut telah merugikan dirinya, yaitu menggunakan kekayaan intelektual tanpa ada hubungan hukum yang sah. ${ }^{5}$

Perlindungan hukum dapat diberikan kepada pencipta, penemu atau pemilik merek, perlindungan ini termasuk ke dalam perlindungan terhadap kekayaan intelektual yaitu perlindungan terhadap hasil olah pikir manusia yang bersifat intangibles atau tidak berwujud atas ciptaan dalam bidang seni, sastra, dan budaya juga terhadap penemu invensi dan lain-lain. Teori yang mendasari perlunya perlindungan hukum terhadap HKI adalah sebagai berikut: ${ }^{6}$

(1) Teori Reward memilik makna mendalam berupa pengakuan terhadap karya intelektual yang dihasilkan oleh seseorang sehingga kepada penemu/pencipta/ pendesain harus diberikan penghargaan sebagai imbalan atas upaya-upaya kreatif nya dalam menemukan atau menciptakan karya-karya intelektual tersebut;

(2) Recovery theory, menyatakan bahwa penemu/pencipta/pendesain yang telah mengeluarkan waktu, biaya, serta tenaga dalam menghasilakan karya intelektual nya harus memperoleh kembali apa yang ditelah dikeluarkannya tersebut;

(3) Incentive theory, mengaitkan pengembangan kreatifitas dengan memberikan insentif pada penemu/pencipta/pendesain tersebut;

$4 \quad$ Ahmad M. Ramli, HAKI Hak atas Kepemilikan Intelektual Teori Dasar Perlindungan Rahasia Dagang, Mandar Madju: Bandung, 2000, hlm. 24-25.

Sudjana, Hak Desain Tata Letak Sirkuit Terpadu, Bandung: Keni Media, 2017, hlm. 68.

6 Robert Sherwood dalam Ranti Fauza Mayana, Perlindungan Desain Industri di Indonesia dalam Era Perdagangan Bebas, Jakarta: Gramedia Widiasarana Indonesia, 2004, hlm. 44-46. 
(4) Risk theory, mengakui bahwa HKI merupakan suatu hasil karya yang mengandung risiko yang dapat memungkinkan orang lain yang terlebih dahulu menemukan cara tersebut atau memperbaikinya sehingga dengan demikian adalah wajar untuk memberikan suatu perlindungan hukum terhadap upaya atau kegiatan yang mengandung risiko tersebut; dan

(5) Economic Growth Stimulus Theory, yang mengakui bahwa perlindungan atas HKI merupakan suatu alat dari pembangunan ekonomi.

Melihat kondisi tersebut maka perlindungan HKI sangat diperlukan bagi masyarakat di Maluku Tenggara Barat khususnya dalam pengelolaan terhadap ikan teri biru yang menjadi salah satu bentuk dari ekonomi kreatif masyarakat. Dalam hal ini beberapa alternatif yang dapat dijadikan pedoman dalam perlindungan HKI yaitu perlindungan hukum merek baik secara konvensional atau perlindungan hukum merek secara kolektif, dan juga perlindungan hukum berdasarkan indikasi geografis.

\section{B. Perlindungan Hukum Merek}

Masyarakat Maluku sebagai penghasil ikan teri telah melakukan pengelolaan dalam bentuk kerupuk, sebaiknya diberikan perlindungan hak merek. Hak merek diberikan oleh negara kepada pemilik merek. Jayashere Watal memberikan definisi bahwa: "Trademarks are distinctive signs that are used to distinguish products, whether goods or services, of one undertaking from those of another". Jadi merek mempunyai fungsi sebagai daya pembeda dari barang dan jasa, sehingga perlu dibuat tanda pengenal untuk membedakannya.?

Merek dagang adalah sebuah alat bisnis yang efektif dan dapat menyampaikan pesan yang kuat dan terfokus pada produk, teknologi, kebudayaan dan individu. ${ }^{8}$ Merek sebaiknya mempunyai daya pembeda agar konsumen dapat mengidentifikasi barang dan jasa berasal dari perusahaan tertentu dan dapat membedakan barangnya adalah berbeda dengan barang dan jasa lainnya, sehingga merek mempunyai fungsi sebagai jaminan kualitas dari barang atau produk tersebut juga merek menjadi alat pemasaran yang penting dan dapat mempengaruhi konsumen untuk membeli atau tidak membeli produk di mana merek itu dilekatkan. ${ }^{9}$ Seiring berkembangnya dunia usaha, fungsi merek mengalami perkembangan. Merek tidak hanya sebagai alat untuk mengidentifikasi barang atau jasa melainkan juga memancarkan reputasi dan goodwill yang terdapat dibalik merek tersebut. ${ }^{10}$

Dalam fungsi merek, diharapkan produsen membuat merek yang dilekatkan pada produk tersebut, sehingga dengan adanya merek maka produk tersebut dapat mengidentifikasi bahwa barangnya atau produknya berbeda dengan orang lain juga

7 Jayasjree Watal, Intelectual Property Rights in The WTO and Developing Countries, Netherlands: Kluwer Law, hlm. 50.

$8 \quad$ Kamil Idris, Intellectual Property: A Powerful for Economic Growth, Jenewa: World Intellectual Property Organization, 2003, hlm. 21.

9 Shafeek Seddiq, "Victor Can Keep His Little Secret Unless Victoris Secret is actually Harmed", Tauro Law Review, Vol. 19, No. 4, 2015, hlm. 880-881.

10 Mathias Stresser, "The Rational Basis of Trademark Protection Revisited: Putting the Dilution Doctrine Into context, Fordham Intellectual Property", Media and Entertainment Law Journal, Vol. 10, No. 2, 2011, hlm. 385. 
sebagai jaminan. Perlindungan tersebut dapat diperoleh setelah pemilik merek mendaftarkan mereknya ke Direktorat Jenderal Kekayaan Intelektual Kementerian Hukum dan Hak Asasi Manusia, ini sesuai dengan sistim pendaftaran konstitutif, artinya bahwa hanya pendaftar pertama yang akan mendapatkan perlindungan, sehingga apabila ada pihak lain yang meniru dapat dilakukan permohonan pembatalan merek. Ini sesuai dengan Pasal 76 Undang-Undang Nomor 20 Tahun 2016 tentang Merek dan Indikasi Geografis (UU Merek dan IG).

Tujuan utama perlindungan merek adalah memberikan informasi yang akurat kepada konsumen mengenai sumber dan/atau asal suatu barang dan jasa. Dengan begitu, merek membantu mengurangi biaya dan upaya konsumen dalam mencari suatu produk barang dan/jasa. Konsumen dapat langsung menemukan suatu produk yang dicarinya dengan menggunakan merek yang mempunyai daya pembeda dan mudah untuk diidentifikasi. ${ }^{11}$ Aspek lainnya dalam perlindungan merek adalah memberikan insentif bagi pemilik Merek untuk meningkatkan kualitas produknya. Untuk itu merek diberikan perlindungan hukum dari segala tindakan pelanggaran merek yang dilakukan oleh pihak lain. Tanpa adanya perlindungan hukum terhadap merek maka pihak lain dapat menggunakan merek yang sudah dikenal oleh masyarakat dan menggunakannya untuk menjual produk yang inferior dibandingkan merek aslinya dan merebut konsumen dari merek tersebut. ${ }^{12}$

Maka dari itu, dengan adanya merek pada kerupuk Ikan teri yang dihasilkan akan meningkatkan nilai ekonomi pada kerupuk tersebut yang dapat dianggap sebagai salah satu bentuk dari industri kreatif yang dapat memajukan perekonomian masyarakat setempat. Industri kreatif tidak hanya berpotensi dalam meningkatkan pertumbuhan ekonomi, tetapi juga berdampak luas terhadap perkembangan sosial dan budaya. ${ }^{13}$

\section{Perlindungan Merek Kolektif}

HKI khususnya merek dapat menjadi pendorong bagi kegiatan bisnis seperti misalnya untuk pelaku usaha kecil dan menengah (UMKM). Undang-Undang Nomor 8 Tahun 2008 tentang UMKM memberikan beberapa definisi sebagai berikut:

"Pasal 1 angka 1: Usaha Mikro adalah usaha produktif milik produktif milik orang perorangan dan/atau badan usaha perorangan yang memenuhi kriteria Usaha Mikro sebagaimana diatur dalam UndangUndang ini.

Pasal 1 angka 2: Usaha Kecil adalah usaha ekonomi produktif yang berdirisendiri, yang dilakukan oleh orang perorangan atau badanusaha yang bukan merupakan anak perusahaan atau bukancabang perusahaan yang dimiliki, dikuasai, atau menjadibagian baik langsung

\footnotetext{
Sara Marie Andrzejewski, "Leave Little Guys Alone: Protecting Small Business from Overly Litiguos Corporations and Trademark Infringement Suits", Journal of Intellectual Property Law, Vol. 19, Issue 1, 2016, hlm. 129.

12 Ibid.

13 Ahmad Gusman Catursiswandi, Membangun Sinergi Antara ....., Op.cit., hlm. 185.
} 
maupun tidak langsung dari Usaha Menengah atau Usaha Besar yang memenuhi kriteria Usaha Kecil sebagaimana dimaksud dalam UndangUndang ini.

Pasal 1 angka 3: Usaha Menengah adalah usaha ekonomi produktif yangberdiri sendiri, yang dilakukan oleh orang perorangan ataubadan usaha yang bukan merupakan anak perusahaan ataucabang perusahaan yang dimiliki, dikuasai, atau menjadibagian baik langsung maupun tidak langsung dengan Usaha Kecil atau Usaha Besar dengan jumlah kekayaan bersih atau hasil penjualan tahunan sebagaimana diatur dalam Undang-Undang ini. ..."

Dalam UU Merek dan IG dikenal berbagai macam merek yaitu merek barang dan jasa, merek kolektif dan certification marks. Merek kolektif adalah merek yang digunakan pada barang dan atau jasa dengan karakteristik yang sama yang diperdagangkan oleh beberapa orang atau badan hukum secara bersama-sama untuk membedakan dengan barang dan /jasa sejenis lainnya. Jadi persyaratan merek kolektif adalah memiliki karakteristik yang sama juga harus dilakukan secara bersama-sama anggota masyarakat/kelompok/asosiasi dan diharuskan untuk dilakukan pendaftaran, sehingga masalah biaya lebih murah. Pendaftaran itu menjadi hal yang penting dan akan menimbulkan hak eksklusif bagi pemilik merek, pendaftaran ini mempunyai kepastian hukum.

Menurut sistem konstitutif dengan doktrin prior of filing, bahwa yang berhak atas suatu merek adalah pihak yang mendaftarkan mereknya maka dikenal dengan presumption of ownership. Jadi pendaftaran itu menciptakan suatu hak atas merek tersebut dan pihak ketiga harus menghormati haknya. Dalam merek kolektif memiliki double impact ${ }^{14}$ yaitu terhadap produk dan pelaku usaha, dari segi produk, standar, dan kualitas produk dapat lebih terjaga, karena dalam penggunaan merek kolektif para pelaku usaha mengadakan kesepakatan mengenai sifat, ciri umum serta mutu barang atau jasa yang akan diproduksi dan diperdagangkan. Dampak positif bagi pelaku usaha diantaranya biaya pendaftaran merek kolektif dapat ditanggung secara bersama-sama oleh semua pemegang merek sehingga akan terjangkau. Merek kolektif juga akan memperluas pemasaran sehingga produk tersebut akan mencapai brand recognition dan consumer recognition, ${ }^{15}$ sehingga bagi UMKM yang menghasilkan suatu produk seperti contoh teri melalui proses kreatif, di mana produk ikan teri dapat dibuat beberapa alternatif misalkan penganan lain selain kerupuk.

\section{Perlindungan Penganan Teri Biru Seira Berdasarkan Indikasi Geografis}

Perlindungan berdasarkan alternatif lain yang dapat diterapkan dalam produk ikan teri biru adalah indikasi geografis. Indikasi geografis sangat berkaitan dengan produk unggulan pertanian atau produk lain di luar pertanian seperti kerajinan, produk

14 Ranti Fauza Mayana, Dinamika Hukum Pembangunan, Bandung: P.T. Alumni, 2017, hlm. 362.

15 Ibid. 
makanan seperti resep atau teknik pengolahan makanan seperti Kue Kacang Kyoto, Sosis Frankfurt, atau kemampuan memproduksi seperti Delf Keramik, Besi Toledo. ${ }^{16}$ Pengaturan terkait indikasi geografis diatur dalam Pasal 1 angka 6 UU Merek dan IG yakni sebagai berikut:

"Suatu tanda yang menunjukkan daerah suatu asal suatu barang dan atau produk yang karena faktor lingkungan geografis termasuk faktor alam, faktor manusia atau kombinasi dari kedua faktor tersebut memberikan reputasi, kualitas dan karakteristik tertentu pada barang dan/atau produk yang dihasilkan."

Selanjutnya Pasal 1 angka 1 Peraturan Pemerintah Nomor 51 Tahun 2007 tentang Indikasi Geografis (PP 51/2007), mendefinisikan IG sebagai "suatu tanda yang menunjukkan daerah asal suatu barang, yang karena faktor lingkungan geografis termasuk faktor alam, faktor manusia, atau kombinasi dari kedua faktor tersebut, memberikan ciri dan kualitas tertentu pada barang yang dihasilkan".

Pengaturan tentang IG dalam UU Merek yang lama (Undang-Undang Nomor 15 Tahun 2001) hanya memuat pokok-pokoknya saja, tetapi dalam UU Merek dan IG, pengaturan indikasi geografis terdiri atas $4 \mathrm{Bab}$, mulai Pasal 53 sampai dengan Pasal 71, memuat ketentuan tentang: mekanisme pendaftaran indikasi geografis, jangka waktu pelindungan, penghapusan indikasi geografis, pelanggaran dan gugatan indikasi geografis, pembinaan dan pengawasan indikasi geografis, serta pengaturan mengenai Indikasi Asal. ${ }^{17}$ Terkait dengan pendaftaran indikasi geografis, Pasal 54 ayat (1) menyebutkan bahwa permohonan yang diajukan oleh pemohon yang bertempat tinggal atau berkedudukan tetap di luar wilayah Indonesia wajib diajukan melalui kuasanya di Indonesia. Selanjutnya dalam Pasal 54 ayat (2) Permohonan sebagaimana dimaksud pada ayat (1) hanya dapat didaftar apabila indikasi geografis tersebut telah memperoleh pengakuan dari pemerintah negaranya dan/atau terdaftar sesuai dengan ketentuan yang berlaku di negara asalnya. Selain itu juga indikasi geografis dapat pula didaftarkan berdasarkan perjanjian internasional (Pasal 55 ayat(1)).

Indikasi geografis dilindungi selama terjaganya reputasi, kualitas, dan karakteristik yang menjadi dasar diberikan perlindungan indikasi geografis pada suatu barang, sedangkan ahli yang memeriksa substantif tentang indikasi geografis adalah akademis atau praktisi yang memiliki keahlian dibidangnya terkait dengan indikasi geografis. ${ }^{18}$ Pembinaan indikasi geografis dilakukan oleh pemerintah pusat dan/atau pemerintah daerah sesuai dengan kewenangannya. Pembinaan meliputi:

a. persiapan untuk pemenuhan persyaratan permohonan indikasi geografis;

b. permohonan pendaftaran indikasi geografis;

c. pemanfaatan dan komersialisasi indikasi geografis;

16 Michael Blakeney, "Geographical Indications and Trade", Makalah Queen Mary Intellectual Property, Research Institute Queen Mary and Westfield College, University of London, 2000, hlm. 1.

17 Marmi Emmy Mustafa, Aneka Penegakan Hukum Hak Cipta, Paten, Merek dan Indikasi Geografis, Bandung: P.T. Alumni, 2017, hlm. 107.

18 Ibid., hlm. 109. 
d. sosialisasi dan pemahaman atas pelindungan indikasi geografis;

e. pemetaan dan inventarisasi potensi produk indikasi geografis;

f. pelatihan dan pendampingan;

g. pemantauan, evaluasi, dan pembinaan;

h. pelindungan hukum; dan

i. fasilitasi pengembangan, pengolahan, dan pemasaran barang dan/atau produk indikasi geografis.

Sementara untuk pengawasan dilakukan untuk menjamin tetap adanya reputasi, kualitas dan karakteristik yang menjadi dasar diterbitkannya indikasi geografis; dan mencegah penggunaan indikasi geografis secara tidak sah. ${ }^{19}$

Di Indonesia pengaturan indikasi geografis tidak dibuat dalam suatu undangundang tersendiri tapi dimasukkan dalam undang-undang merek. Secara historis, pengaturan indikasi geografis pada awalnya terdapat dalam Pasal 79 A sampai Pasal 79 E Undang-Undang Nomor 14 Tahun 1997 tentang Merek (UU Merek 1997). Pengaturan indikasi geografis di dalam UU Merek 1997 merupakan hal baru sebagai penyesuaian ketentuan yang terdapat dalam The Agreement on Trade Related Aspect of Intellectual Property Rights (TRIPs). UU Merek sebelumnya yaitu UndangUndang Nomor 21 Tahun 1961 dan Undang-Undang Nomor 19 Tahun 1992 belum mengatur perlindungan indikasi geografis. Terakhir, indikasi geografis dimasukkan sebagai bagian judul undang-undang terbaru, yakni UU Merek dan IG. ${ }^{20}$ Produk yang dilindungi dalam rezim indikasi geografis pada awalnya sebatas pada wine dan spirit, tetapi pada perkembangannya juga meliputi produk keju, daging segar, sayur segar, dan sebagainya.

Legalitas kepemilikan perlu dilakukan untuk suatu produk yang mempunyai ciri khas dan mempunyai rasa yang berbeda dengan produk lain sehingga dapat memberikan kepastian hukum siapa pemilik dari produk tersebut. Hal ini dapat memperjelas keberadaannya dan menjadi milik sah dari masyarakat. Indonesia memberikan perlindungan berdasarkan indikasi Geografis melalui pendaftaran dengan tujuan memperoleh perlindungan selama ciri dan/atau kualitas yang menjadi dasar kualitas tersebut masih ada, sehingga indikasi geografis yang sudah didaftarkan tidak dapat menjadi milik publik atau menjadi milik umum.

PP 51/2007 juga mengatur bahwa yang dapat dilindungi oleh Indikasi geografis dapat berupa hasil pertanian, produk olahan, hasil kerajinan tangan atau barang lainnya. Sedangkan pihak yang dapat mendaftarkan Indikasi Geografis diatur dalam Pasal 53 Ayat 1 dan Pasal 5 Ayat 3 PP 51/2007, adalah:

a. Lembaga yang mewakili masyarakat di kawasan geografis tertentu yang mengusahakan suatu barang dan atau produk berupa:

\footnotetext{
Ibid., hlm. 110.

20 Mas Rahmah, "Hak Milik Industri, Perlindungan Indikasi Geografis untuk Produk Pertanian: Skenario untuk Mendukung ketahanan Pangan", Makalah disampaikan pada konferensi internasional Symphonizing Intellectual Property and Potential Resources For Public Welfare di Fakultas Hukum Universitas Mataram bekerja sama dengan Asosiasi Pengajar Hak Kekayaan Intelektual Indonesia, Nusa Tenggara Barat-Indonesia, 20-23 Agustus 2017, hlm. 82.
} 
1) Sumber daya alam;

2) Barang kerajinan tangan; atau

3) Hasil industri.

b. Pemerintah Daerah Provinsi atau Kabupaten/Kota.

Untuk kepentingan proses pendaftaran maka diangkat Tim Ahli Indikasi Geografis yang diangkat berdasarkan Surat Keputusan Menteri Hukum dan HAM Tahun 2008. Perlindungan indikasi geografis tersebut diberikan sebuah tanda berupa logo untuk menjamin keaslian, ciri, kualitas dan karakteristik produk dalam menjaga, melindungi dan memanfaatkan secara ekonomi suatu produk dari wilayah tertentu. Menurut Tim Ahli Indikasi Geografis Direktorat Kekayaan Intelektual pemberian logo itu mempunyai makna yaitu:

1) Bunga teratai hidup di 3 (tiga) alam, darat atau tanah, air dan udara;

2) Daun maupun bunganya keluar dan tangkai yang berasal dari rimpang yang berada dia dalam lumpur pada dasar kolam, sungai, atau rawa yang mempunyai makna bahwa alam Indonesia yang berada di antara 2 (benua) dan 2 (dua) samudera serta (dua) musim menghasilkan keanekaragaman hayati dan merupakan sumber produk Indikasi Geografis dan;

3) Lima lima pasang mahkota bunga teratai melambangkan 5 (lima) dasar Negara Kesatuan Republik Indonesia yaitu Pancasila.

Perlindungan indikasi geografis dapat meningkatkan output produksi dan nilai tambah produksi terlihat dengan meningkatnya harga indikasi geografis juga dapat memperkuat daya saing produk unggulan pertanian di pasar domestik maupun internasional karena dalam perdagangan internasional di samping harga, sebagian besar persaingan terletak pada ciri khas, keunggulan dan konsistensi mutu produk. ${ }^{21}$ Beberapa pakar mengemukakan tentang manfaat perlindungan indikasi geografis, dalam hal ini Yustina Linasari mengemukakan manfaat perlindungan indikasi geografis sebagai berikut:22

1) Melindungi produk dan produsen anggota kelembagaan indikasi geografis terhadap kecurangan, penyalahgunaan dan pemalsuan tanda indikasi geografis;

2) Meningkatkan posisi tawar produk serta kemampuan memasuki pasar baru pada tataran nasional maupun internasional;

3) Meningkatkan nilai tambah, meningkatkan lapangan kerja, meningkatkan lapangan kerja, meningkatkan kualitas produk, meningkatkan produksi, meningkatkan peluang diversifikasi produk;

4) Memberikan informasi yang jelas kepada konsumen tentang jenis kualitas dan asal produk yang mereka beli;

5) Meningkatkan peluang promosi untuk memperoleh reputasi yang lebih baik;

6) Meningkatkan pendapatan dan kesejahteraan pelaku usaha;

7) Meningkatkan perekonomian dan mempercepat pembangunan wilayah;

Ibid, hlm. 96.

22 Yustina Linasari, "Perlindungan Potensi Alam Indonesia melalui Indikasi Geografis", Media HKI, Vol XIV/ Edisi III/2017, hlm. 4. 
8) Menjaga kelestarian lingkungan untuk menjamin keberadaan ciri dan kualitas produk; dan

9) Menjaga kelestarian budaya bangsa yang terkait dengan kualitas dan reputasi suatu barang indikasi geografis.

Emawati Yunus mengemukakan perlindungan indikasi geografis akan memberikan kontribusi sebagai berikut: ${ }^{23}$

a) Memberikan perlindungan hukum bagi produk indikasi geografis di Indonesia;

b) Dapat digunakan sebagai strategi pemasaran untuk produk indikasi geografis di dalam perdagangan;

c) Memberikan nilai tambah pada produk yang berpotensi indikasi geografis dan meningkatkan kemampuan ekonomi daerah;

d) Meningkatkan reputasi produk indikasi geografis pada perdagangan global; dan

e) Sebagai salah satu alat untuk menghindari persaingan curang.

f) Indikasi geografis memiliki signifikansi yang cukup tinggi bagi Indonesia karena beberapa alasan sebagai berikut: ${ }^{24}$

g) Sebagai penandatanganan perjanjian TRIPs, adanya sistem perlindungan indikasi geografis yang implementatif ditingkat nasional akan meningkatkan integritas Indonesia di mata dunia internasional;

h) Adanya keuntungan bagi negara pemula untuk memilih sistem indikasi geografis yang cocok dengan kepentingan nasionalnya dalam masa transisi ini. Karena sistem implementasi perlindungan indikasi geografis yang sekarang berlaku secara internasional masih amat beragam dan belum disepakati bersama, Indonesia dapat mempergunakan kedaulatannya untuk membangun sistem sendiri yang paling cocok bagi kepentingan nasional, sesuai dengan nilai-nilai masyarakatnya sendiri, sambil terus mengacu kepada prinsip-prinsip dasar TRIPs;

i) Karakter kepemilikan indikasi geografis yang kolektif atau komunalistik sejalan dengan nilai-nilai ketimuran dan keindonesiaan yang lebih menghargai kepemilikan bersama dari pada kepemilikan pribadi;

j) Keharusan adan-ya kaitan atau hubungan yang erat (strong link) antara nama atau indikasi produk dengan kondisi geografis asal produk dalam rezim indikasi geografis tampak sejalan dengan sifat-sifat hukum masyarakat Adat yang selalu menjunjung ketergantungan dan kelestarian eksistensinya dengan tanah asal. Potensi Indikasi geografis ini dapat dikembangkan untuk melindungi produkproduk masyarakat adat dan komunitas lokal yang umumnya dinamai bukan dengan nama individu, tetapi nama tempat asal suatu produk yang akan dilindungi dengan indikasi geografis;

k) Jangka waktu perlindungan indikasi geografis yang terus-menerus membuatnya

23 Emawati Yunus, "Pentingnya Perlindungan Indikasi Geografis Sebagai Bagian dari Hak Kekayaan Intelektual dan Pelaksanaannya di Indonesia", Makalah disampaikan pada Seminar Nasional Perlindungan Indkasi Geografis di Indonesia, Jakarta, 2004.

24 Miranda Risang Ayu, Memperbincangkan Hak Kekayaan Intelektual Indikasi Geografis, Bandung: P.T. Alumni, 2006, hlm. 8. 
berpotensi untuk melindungi keberlangsungan aset bangsa atau aset historis suatu komunitas lokal agar tetap tinggi dan bermanfaat bagi bangsa atau kelompok masyarakat pengembangnya sendiri;

I) Di negara maju sekali pun, misalnya Perancis, indikasi geografis merupakan salah satu rezim HKI yang telah terbukti dapat meningkatkan derajat ekonomi komunitas lokal yang miskin, terpencil dan hanya memiliki satu sektor ekonomi andalan, untuk menjadi basis penguatan infrastruktur lokal yang independen

Kontribusi perlindungan hukum indikasi geografis akan memberikan manfaat baik bagi produsen maupun bagi konsumen. Bagi konsumen, perlindungan hukum indikasi geografis antara lain memberi jaminan kualitas produk sesuai harapan konsumen, dan memberikan jaminan hukum bagi konsumen. ${ }^{25}$ Bagi produsen, manfaat indikasi geografis dapat dilihat dari aspek ekonomi, aspek ekologi, aspek sosial budaya dan aspek hukum. Ditinjau dari aspek ekonomi, yaitu adanya kepemilikan suatu produk yang berkualitas dan berciri khas, peningkatan nilai tambah, peningkatan pemasaran, perlindungan dari pemalsuan produk, peningkatan pendapatan, peningkatan lapangan kerja, keberlanjutan usaha, percepatan pengembangan wilayah serta peningkatan kesejahteraan masyarakat. Ditinjau dari aspek ekologi; yaitu menjaga kelestarian alam, mempertahankan kelestarian sumber daya genetik serta peningkatan reputasi kawasan. Ditinjau dari aspek sosial budaya; mempererat hubungan komunitas produsen, meningkatkan dinamika wilayah, melestarikan adat, pengetahuan serta kearifan lokal masyarakat. Ditinjau dari aspek hukum; memberikan perlindungan dan kepastian hukum bagi produsen dan perlindungan dari pemalsuan dan pemanfaatan legal, serta ketenaran produk. ${ }^{26}$

Setelah produk yang dilindungi oleh indikasi geografis dan telah diberi logo, maka produk tersebut telah mendapatkan perlindungan sehingga orang lain atau pihak ketiga tidak boleh memakai logo tersebut. Hal yang termasuk pelanggaran Indikasi geografis dalam UU Merek dan IG adalah sebagai berikut:

a. Pemakaian indikasi geografis yang bersifat komersial, baik secara langsung maupun tidak langsung atas barang yang tidak memenuhi Dokumen Deskripsi Indikasi Geografis;

b. Pemakaian suatu tanda indikasi geografis yang bersifat komersial, baik secara langsung maupun tidak langsung atas barang yang dilindungi atau tidak dilindungi dengan maksud untuk menunjukkan bahwa barang tersebut sebanding kualitasnya dengan barang yang dilindungi oleh indikasi geografis, untuk mendapatkan keuntungan dari pemakaian tersebut;

c. Pemakaian indikasi geografis yang dapat menyesatkan masyarakat sehubungan dengan asal usul barang;

d. Pemakaian indikasi geografis tanpa hak sekalipun asal barang dinyatakan;

e. Peniruan atau penyalahgunaan lainnya yang dapat menyesatkan sehubungan dengan asal tempat barang atau kualitas barang yang tercermin dari pernyataan

25 Emawati Yunus, Loc. cit.

26 Ibid. 
pada pembungkus atau kemasan, keterangan dalam iklan, keterangan dalam dokumen mengenai barang tersebut, informasi yang dapat menyesatkan mengenai asal usulnya dalam pengepakan barang dalam suatu kemasan;

f. Tindakan lainnya yang dapat menyesatkan masyarakat luas mengenai kebenaran asal barang tersebut.

Indikasi geografis adalah salah satu rezim HKI yang paling banyak dipengaruhi oleh nilai-nilai budaya setempat, baik dalam konteks negara maupun lokal. Produk unggulan suatu daerah atau negara yang telah dilindungi oleh indikasi geografis biasanya merupakan pencerminan langsung dari nilai budaya setempat yang dominan. Karena kekhasan sistem perlindungan yang mengusung nama tempat asli suatu produk, perlindungan indikasi geografis juga sering kali bersentuhan dengan aspek-aspek yang berkaitan dengan perlindungan pengetahuan tradisional, terutama karena banyak sekali produk kekayaan tradisional yang dikelola secara kolektif, dari generasi ke generasi, dan dikenal dengan nama tempat asal. ${ }^{27}$

\section{E. Pendaftaran Indikasi Geografis dan Kendala yang dihadapi atas Penganan Teri Biru Seira}

Perlindungan terhadap indikasi geografis adalah setelah indikasi geografis didaftarkan oleh menteri. Untuk memperoleh pelindungan, terlebih dahulu pemohon indikasi geografis harus mengajukan permohonan kepada menteri yang bersangkutan. Pemohon yang mengajukan permohonan kepada menteri merupakan (a) lembaga yang mewakili masyarakat di kawasan geografis tertentu yang mengusahakan suatu barang dan/atau produk berupa sumber daya alam; atau barang kerajinan tangan; atau hasil industri; atau (b) pemerintah daerah provinsi atau kabupaten/kota. Penganan yang dibuat dari teri biru Seira termasuk dalam kategori 'hasil industri' kreatif masyarakat di Tanimbar.

Pemohon yang mengajukan permohonan pendaftaran kepada menteri merupakan lembaga yang mewakili masyarakat. Maka terlebih dahulu penting untuk dilakukan penguatan lembaga yang mewakili masyarakat yang merupakan produsen berbasis produk indikasi geografis. Dalam hal ini karena proses sertifikasi produk indikasi geografis tidak dapat dilakukan oleh dan diberikan kepada individu, melainkan oleh atau kepada masyarakat asosiasi produsen sehingga pembentukan atau penguatan kelompok atau asosiasi produsen produk indikasi geografis sangat diperlukan.

Pada proses pendaftaran terdapat pemeriksaan substantif yang membutuhkan waktu paling lama 2 (dua) tahun. Pada pemeriksaan substansi yang diperiksa adalah antara lain kesesuaian pernyataan di Buku Persyaratan Pendaftaran dengan keaqdaan yang sebenarnya. Menurut Pasal 8 Ayat (3) PP 51/2007, pemeriksaan substantif dilaksanakan berdasarkan ketentuan dalam Pasal 1 angka 1, Pasal 3, dan Pasal 6 Ayat (3) PP 51/2007 mengatur bahwa indikasi geografis adalah suatu tanda yang menunjukkan daerah asal suatu barang, yang karena faktor lingkungan

27 Miranda Risang Ayu, Op.cit., hlm. 185-186. 
geografis termasuk faktor alam, faktor manusia atau kombinasi dari kedua faktor tersebut, memberikan ciri dan kualitas tertentu pada barang yang dihasilkan. Pasal 3 PP 51/2007 mengatur bahwa indikasi geografis tidak dapat didaftar apabila tanda yang dimohonkan pendaftarannya :

a. bertentangan dengan peraturan perundang-undangan, moralitas agama, kesusilaan atau ketertiban umum;

b. menyesatkan atau memperdaya masyarakat mengenai: ciri, sifat, kualitas, asal, sumber, proses pembuatan barang, dan/atau kegunaannya;

c. merupakan nama geografis setempat yang telah digunakan sebagai nama varietas tanaman, dan digunakan bagi varietas tanaman yang sejenis; atau

d. telah menjadi generik.

Pasal 6 Ayat (3) PP 51/2007 mengatur bahwa permohonan sebagaimana dimaksud pada ayat (1) harus dilengkapi dengan Buku Persyaratan yang terdiri dar :

a. nama Indikasi-geografis yang dimohonkan pendaftarannya;

b. nama barang yang dilindungi oleh indikasi geografis;

c. uraian mengenai karakteristik dan kualitas yang membedakan barang tertentu dengan barang lain yang memiliki kategori sama, dan menjelaskan tentang hubungannya dengan daerah tempat barang tersebut dihasilkan;

d. uraian mengenai lingkungan geografis serta faktor alam dan faktor manusia yang merupakan satu kesatuan dalam memberikan pengaruh terhadap kualitas atau karakteristik dari barang yang dihasilkan;

e. uraian tentang batas-batas daerah dan/atau peta wilayah yang dicakup oleh indikasi geografis;

f. uraian mengenai sejarah dan tradisi yang berhubungan dengan pemakaian indikasi geografis untuk menandai barang yang dihasilkan di daerah tersebut termasuk pengakuan dari masyarakat mengenai indikasi geografis tersebut;

g. uraian yang menjelaskan tentang proses produksi, proses pengolahan, dan proses pembuatan yang digunakan sehingga memungkinkan setiap produsen di daerah tersebut untuk memproduksi, mengolah, atau membuat barang terkait;

h. uraian mengenai metode yang digunakan untuk menguji kualitas barang yang dihasilkan; dan

i. label yang digunakan pada barang dan memuat indikasi geografis.

Di dalam pemeriksaan substantif terutama akan diperiksa apakah tanda yang dimohonkan pendaftaran masuk sebagai indikasi geografis atau tidak, dan apakah tanda yang dimohonkan indikasi geografis tersebut, tidak mengandung unsur-unsur sebagaimana disebut dalam Pasal 3 PP 51/2007.

Menurut ketentuan Pasal 56 Ayat (1) UU Merek dan IG, Permohonan indikasi geografis tidak dapat didaftarkan jika:

a. bertentangan dengan ideologi negara, peraturan perundang-undangan, moralitas, agama, kesusilaan, dan ketertiban umum;

b. menyesatkan atau memperdaya masyarakat mengenai reputasi, kualitas, karakteristik, asal sumber, proses pembuatan barang, dan/atau kegunaannya; 
dan

c. merupakan nama yang telah digunakan sebagai varietas tanaman dan digunakan bagi varietas tanaman yang sejenis, kecuali ada penambahan padanan kata yang menunjukkan faktor indikasi geografis yang sejenis.

Menurut ketentuan Pasal 56 Ayat (2) Undang-Undang Merek, Permohonan Indikasi Geografis ditolak jika:

a. Dokumen Deskripsi Indikasi Geografis tidak dapat dibuktikan kebenarannya; dan/atau

b. memiliki persamaan pada keseluruhannya dengan indikasi geografis yang sudah terdaftar.

Berdasarkan uraian di atas, dapat dikemukakan bahwa untuk mempromosikan dan melindungi produk indikasi geografis terdapat kendala yaitu pada pengawasan kualitas dan ciri khas indikasi geografis. Hal ini mengingat menurut Anson C.J dalam International Journal of Marketing, Financial Services \& Management Research, ${ }^{28}$ bahwa indikasi geografis merupakan hak yang sifatnya kolektif yang kepemilikannya tidak bisa dimiliki oleh individu namun dipegang oleh kelompok masyarakat, maka ada kesulitan untuk melakukan pengelolaan dan pengawasan kualitas produk yang berbasis indikasi geografis merupakan hal yang sangat penting, karena tujuan utama dari perlindungan indikasi geografis adalah untuk melindungi dan memelihara reputasi dari indikasi geografis sehingga melindungi kualitas merupakan faktor yang sangat penting agar perlindungan indikasi geografis tetap diberikan.

Syarat bahwa kualitas produk menjadi syarat untuk perlindungan atas indikasi geografis diatur di dalam UU Merek dan IG, bahwa indikasi geografis terdaftar tetap mendapat perlindungan hukum yang berlangsung selama ciri dan/atau kualitas yang menjadi dasar bagi diberikannya perlindungan atas indikasi geografis tersebut masih ada. Sebagaimana diuraikan sebelumnya bahwa tidaklah mudah mengontrol kualitas dan karakteristik khas yang dimiliki oleh produk yang berbasis indikasi geografis. Begitu indikasi geografis menjadi terkenal dan sukses di pasaran, akan banyak pihak yang masuk di area geografis di mana produk berbasis indikasi geografis diproduksi untuk mengambil manfaat atau keuntungan dari keunggulan indikasi geografis.

Sebagai konsekuensi dari kepemilikan indikasi geografis yang bersifat kolektif, indikasi geografis tidak terbatas penggunaannya oleh produsen atau satu grup saja tetapi produsen lain bisa menggunakan asalkan mengajukan permohonan untuk menggunakan indikasi geografis dengan memenuhi syarat-syarat penggunaan sesuai dengan peraturan penggunaan yang ditetapkan oleh pemegang indikasi geografis. Dengan banyaknya produsen yang masuk untuk memproduksi produk yang berbasis indikasi geografis dan menggunakan nama indikasi geografis tersebut, maka akan menyebabkan meningkatnya produksi, sehingga dapat mengurangi keterbatasan produk (scarcity) yang akan mengurangi nilai jual yang tinggi dari produk (premium related to the product). Selain itu ada kemungkinan bahwa apabila setiap grup

28 Mas Rahmah, “Hak Milik Industri Perlindungan Indikasi Geografis...", Op.cit., hlm.112-113. 
memiliki hak yang sama untuk memproduksi barang berbasis indikasi geografis, mereka mungkin akan memproduksi barang sesuai pesanan konsumennya sehingga dapat mengurangi kualitas produk. Apabila satu saja produsen menghasilkan produk indikasi geografis berkualitas rendah, hal ini akan berakibat buruk pada kelompok produsen secara keseluruhan dan pada periode tertentu dapat merusak reputasi produk yang bersangkutan.

\section{F. Penutup}

Berdasarkan uraian di atas dapat disimpulkan bahwa produk penganan kerupuk ikan teri biru seira dapat diberikan perlindungan HKI sebagai berikut:

1. Hukum Merek;

2. Merek Kolektif; dan

3. Indikasi Geografis,

Dari beberapa bentuk perlindungan HKI tersebut, yang paling efektif melindungi produk kerupuk ikan teri biru seira dan produk derivatifnya adalah indikasi geografis dengan alasan pengaruh yang kuat dari faktor alam, atau faktor manusia, dan/ atau kombinasi dari kedua faktor tersebut dinyatakan sebagai indikator daerah asal produk yang memberikan ciri dan kualitas tertentu pada produk yang dihasilkan. Selain itu, beberapa saran dari Tim Penulis adalah sebagai berikut:

1. Pentingnya melaksanakan perlindungan indikasi geografis atas produk Teri Biru Seira dan Kerupuk Ikan Tanimbar, melalui pendaftaran merek kolektif oleh pemohon yang diwakili oleh komunitas masyarakat, koperasi atau UMKM untuk memberikan kepastian hukum dan tidak akan terjadi kesalahpahaman masyarakat tentang asal barang atau produk itu berasal.

2. Pentingnya peran aktif pemerintah daerah setempat mewakili komunitas masyarakat yang bersangkutan dengan memperhatikan syarat pendaftaran yang tercantum dalam buku pendaftaran indikasi geografis;

3. Pentingnya kerja sama pemerintah daerah setempat dengan perguruan tinggi (dengan Universitas Padjadjaran atau Universitas Pattimura) untuk menyusun langkah-langkah dalam proses pembuatan kedua produk indikasi geografis.

\section{Daftar Pustaka}

\section{Buku}

Ahmad Gusman Catursiswandi, Membangun Sinergi antara Warisan Budaya Tradisional, Keanekaragaman Hayati dan Ekonomi Kreatif: Perspektif Hak Kekayaan Intelektual, Dinamika Hukum dalam Pembangunan Berkelanjutan, P.T. Alumni, Bandung, 2017.

Ahmad M. Ramli, HAKI Hak atas Kepemilikan Intelektual Teori Dasar Perlindungan Rahasia Dagang, Penerbit Mandar Madju, Bandung, 2000.

Idris, Kamil, Intellectual Property: A Powerful for Economic Growth, World Intellectual Property Organization, Jenewa, 2003.

Marmi Emmy Mustafa, Aneka Penegakan Hukum Hak Cipta, Paten, Merek dan 
Indikasi Geografis, P.T. Alumni, Bandung, 2017.

Miranda Risang Ayu, Memperbincangkan Hak Kekayaan Intelektual Indikasi Geografis, P.T. Alumni, Bandung, 2006.

Ranti Fauza Mayana, Perlindungan Desain Industri di Indonesia Dalam Era Perdagangan Bebas, Gramedia Widiasarana Indonesia, Jakarta, 2004. , Dinamika Hukum Pembangunan, P.T. Alumni, Bandung, 2017.

\section{Dokumen Lain}

Andrzejewski, Sara Marie, "Leave Little Guys Alone: Protecting Small Business from Overly Litiguos Corporations and Trademark Infringement Suits", Journal of Intellectual Property Law, Vol. 19, Issue 1, 2016.

Badan Pemberdayaan Masyarakat Desa Kabupaten Maluku Tenggara Barat Kerjasama dengan Direktorat Riset dan Pengabdian kepada Masyarakat Universitas Padjadjaran, "Program Implementasi Teknologi Tepat Guna Untuk Meningkatkan Pendapatan Keluarga di Kabupaten Maluku Tenggara Barat Provinsi Maluku", Laporan Akhir, 2016.

Blakeney, Michael, "Geographical Indications and Trade", Makalah Queen Mary Intellectual Property, Research Institute Queen Mary and Westfield College, University of London, 2000.

Mas Rahmah, "Hak Milik Industri, Perlindungan Indikasi Geografis untuk Produk Pertanian: Skenario untuk Mendukung ketahanan Pangan", Makalah disampaikan pada konferensi internasional Symphonizing Intellectual Property and Potential Resources For Public Welfare di Fakultas Hukum Universitas Mataram bekerja sama dengan Asosiasi Pengajar Hak Kekayaan Intelektual Indonesia, Nusa Tenggara Barat-Indonesia, 20-23 Agustus 2017.

Seddiq, Shafeek, "Victor Can Keep His Little Secret Unless Victoris Secret is Actually Harmed", Tauro Law Review, Vol. 19, No. 4, 2015.

Stresser, Mathias, "The Rational Basis of Trademark Protection Revisited: Putting the Dilution Doctrine Into context, Fordham Intellectual Property", Media and Entertainment Law Journal, Vol. 10, No.r 2, 2011.

\section{Dokumen Hukum}

Undang-Undang Nomor 14 Tahun 1997 tentang Merek.

Undang-Undang Nomor 20 Tahun 2016 tentang Merek dan Indikasi Geografis.

Peraturan Pemerintah Republik Indonesia Nomor 51 Tahun 2007 tentang Indikasi Geografis. 